\title{
Menegakkan Syariah Compliance dalam Pasar Modal Syariah
}

\author{
Agus Triyanta
}

\begin{abstract}
In view of common people, every financial institution is almost called as a bank, and their image about bank is creditor, and the creditor is usury. Based on this assumption, the breakthrough opening syariah (Islamic law) stock exchange in which it is far from the usury and the substance of proscribed. It is the handicaps for all Islamic business as well as the appropriate moment to wake the Moslem consciousness an the importance and legality of business through investment and as the other altemative of the economic system.

\section{Pendahuluan}

Pasar Modal Syariah telah resmi dibuka pada Desember 2003. Hal ini merupakan perkembangan yang 'setady' dari proses Islamisasi ekonomi umat Islam. Sejak diizinkannya bank non bunga untuk beroperasi di Indonesia dengan Undang-Undang Nomor 7 Tahun 1992 tentang Perbankan (UUP) setelah sebelumnya dalam Pakto 1988 hanya disebutkan bolehnya bank menerapkan bunga nol. Bagaikan terbukanya pintu kran bagi 'Islamisasi Lembaga Keuangan', dalam waktu yang tidak lebih dari satu dekade berikutnya, perkembangan yang terjadi sangat menjanjikan. Berawal dari berdirinya Bank Muamalat Indonesia sebagai 'yang pertama sesuai syariah' segera setelah UUP, hingga hari ini banyak perkembangan telah dicapai. Dari dimungkinkannya membuka window dan dirubah menjadi unit syariah bagi bank konvensional, hingga berlanjut ke asuransi syariah, obligasi syariah, reksadana syariah,

dan yang terakhir ini adalah pasar modal syariah dan Badan Arbritase Muamalah Indonesia (BAMUI). Berdirinya pasar modal syariah ini, berbagai peluang dan tantangan sangat mungkin dan terbuka untuk didiskusikan.

Apa saja permasalahan di seputar pasar modal syariah, utamanya pada aspek Syariah compliance (kesesuaian dengan aturan syariah), sebagai bagian dari sistem pengawasan yang harus ditegakkan terhadap pasar modal syariah? Bagaimana natur dari pasar modal konvensional serta berbagai potensi pelanggaran akan aturan yang ada di dalamnya? Bagaimana pasar modal syariah memainkan peran bagi pengembangan ekonomi masyarakat dengan segenap nilai lebih yang built in di dalamnya? Akhirnya, bagaimana jaminan terhadap kesesuaian dengan prinsip-prinsip syariah harus diupayakan, dan bagaimana Syariah compliance harus dilakukan? 


\section{Urgensi Pasar Modal}

Dunia ekonomi mengenal tiga jenis pasar utama; yaitu pasar barang dan jasa, pasar faktor produksi, serta pasar finansial. Pasar barang dan jasa diperjualbelikan berbagai macam barang hasil produksi serta berbagai bentuk jasa. Pasar faktor produksi satu pihak memberikan tanah, modal, tenaga kerja atau manajemen kepada pihak lain dengan kompensasi sewa, bunga, laba, bagi hasil, dan sejenisnya. Pada pasar finansial masyarakat yang memiliki dana menawarkan kepada perusahaan melalui instrumeninstrumen tertentu. Pasar finansial ini terdiri dari dua jenis, yaitu pasar uang dan pasar modal. Pasar uang lebih bersifat jangka pendek (jual beli tabungan, deposito, surat utang jangka pendek), sedangkan pasar modal bersifat jangka panjang, instrumennya berbentuk saham dan obligasi. ${ }^{1}$

Melihat berbagai macam bentuk pasar tersebut, juga dapat dilihat, bahwa pasar modal merupakan. bentuk pasar yang paling modern, yang berkembang sejalan dengan perkembangar kehidupan ekonomi. Dalam perkembangan ekonomi yang masih bersifat elementer, tentunya lebih diwarnai dengan bentuk perdagangan berkaitan dengan pertukaran barang secara langsung. Namun, ketika kehidupan ekonomi sudah diwarnai dengan berbagai tcontuk bidang usaha, yang perluasan dan pengembangan usaha tersebut memerlukan penambahan modal, maka pasar modal menjadi salah satu alternatif yang dibuat untuk memfasilitasi keinginan berinvestasi. Karenanya, pasar modal bukan hanya penting bagi pencarian dana segar bagi sebuah entitas bisnis yang ada, namun lebih dari itu, menjadi arena bagi orang yang memiliki ke!ebihan dana untuk melakukan investasi dalam bidang usaha yang diinginkan.

Beberapa urgensi yang mendasari harus dikembangkannya pasar modal, ialah, pertama, sebagai sarana untuk menghimpun dana-dana masyarakat untuk disalurkan ke dalam kegiatan-kegiatan yang produktif. Kedua, merupakan sumber pembiayaan yang mudah, murah dan cepat bagi dunia usaha. Ketiga, pasar modal mendorong terciptanya kesempatan berusaha Jan sekaligus menciptakan kesempatan kerja, serta keberadaan pasar modal akan mempertinggi efisiensi alokasi sumber produksi. ${ }^{2}$

Pasar modal, karenanya, merupakan sebuah konsekuensi dari hukum pasar, di mana orang dapat ikut serta dalam kepemilikan sebuah perusahaan selama orang tersebut mampu untuk melakukan pembelian. Demikian halnya dengan pihak penjual, mereka dapat memperoleh dana bagi pengembangan perusahaan tersebut. Dengan demikian, keceradaan pasar modal merupakan salah satu instrumen pasar modern yang akan mempertinggi tingkat saving masyarakat dalam sektor produksi yang aktif, dan mampu menggerakkan perekonomian menuju aktivitas pasar yang lebih dinamis.

'Sentanue Kertcnegoro, Pasar Uang Pasar Modal (Jakarta: Yayasan Tenaga Kerja Indonesia, 1999), hlm. 1.

${ }_{2}^{2}$ M!nir F!!zdy. Pàsar Modal Modem (Tinjauan Umum) (Bandung: Citra Aditya Bakti, 1996), hlm. 11 - 12. 


\section{Sifat Dasar Pasar Modal}

Pasar modal, bagaimanapun juga adalah sebuah 'pasar' yang tidak dapat dilepaskan dari realita kelemahan yang ada pada khasnya sebuah pasar; ialah berbagai bentuk kecurangan (fraud atau tadlis). Di medan inilah hukum ekonomi tumbuh dan berkembang; mencari keuntungan sebanyak-banyaknya dengan modal yang sekecil-kecilnya. Adanya berbagai bentuk upaya yang muaranya menguntungkan diri sendiri dan merugikan pihak lain menjadi keniscayaan. Beberapa hal yang dapat dicatat sebagai bentuk yang dapat merugikan dalam dunia pasar modal diuraikan berikut ini.

\section{Spekulasi}

Spekulasi memang tidak selamanya merugikan, karena di antara faktor yang menyebabkan pasar tetap aktif adalah adanya aktivitas spekulasi. Namun, dalam tingkat tertentu, spekulasi ini akan membawa kerugian yang berdampak luas. Beik mencatat ada beberapa kerugian yang diakibatkan oleh tindakan spekulasi ini. Spekulasi telah memberikan bagi pelakunya apa yang disebut dengan unearned income (penghasilan yang tanpa diupayakan). Spekulan mengambil keuntungan tanpa kontribusi yang bersifat produktif, mereka mengambil keuntungan atas biaya masyarakat. Yang lebih. membahayakan, spekulasi dilakukan atas dasar spirit 'jalan pintas' untuk meraih kekayaan. Hal ini, acap kali mengabaikan etika ekonomi, moral, sosial, dan religius. ${ }^{3}$

Tidaklah mengherankan apabila tindakan semacam ini mengakibatkan terjadinya krisis di Wall Street tahun 1929, yang efek dominonya dikenal dengan the Great Depression, yang menggoncang perekonomian dunia di tahun 1930-an. Bukan hanya itu, terjadinya devaluasi Poundsterling di Inggris tahun 1967 serta krisis mata uang Franc di tahun 1969 juga terjadi dikarenakan sebab-sebab yang tidak dapat dilepaskan dari adanya tindakan spekulasi. ${ }^{4}$

\section{Penipuan}

Penipuan dan berbagai bentuk kecurangan merupakan suatu hal yang bukan hanya mungkin, namun sudah banyak terjadi dalam pasar modal (di lantai bursa). Penipuan ini dapat terkait dengan proses atau mekanisme dan dapat pula berkait dengan saham yang diperjualbelikan. Bursa Efek Jakarta tercatat sudah berkali-kali kebobolan untuk kasus penipuan.

Di antara bentuk penipuan tersebut adalah pemalsuan saham. Sama halnya dengan uang serta berbagai surat berharga (commercial papers), saham pun sangat mungkin untuk dipalsukan. Kejadian yang terjadi di bursa ini adalah suatu hal biasa, yang jika tidak dicermati akan menimbulkan kerugian berbagai pihak dan menurunkan kredibilitas bursa. Kejahatan lain sejenis yang muncul

\footnotetext{
${ }^{3}$ Irfan Syauqi Beik, "Prinsip Pasar Modal Syariah", http://www. pesantrenvirtual.com/ekonomi/001.shtml,
} 27 April 2004, jam 10.17.

${ }^{4}$ lbid. 
adalah penjualan saham yang belum tercatat di bursa. ${ }^{5}$ Hal ini dapat terjadi karena adanya berbagai strategi yang masih dapat dilakukan untuk mengelabuhi para investor, sehingga saham yang belum terdaftar pun dapat diperjualbelikan di bursa efek.

\section{Window Dressing}

Window dressing merupakan salah satu kejahatan yang biasa muncul dalam aktivitas pasar modal di bursa efek, ialah berupa pembuatan mark-up terhadap informasi yang berkaitan dengan perusahaan yang akan menjual sahamnya. Dengan perkataan lain, melakukan manipulasi data terhadap informasi dalam porspektus, informasi tertulis sehubungan dengan penawaran umum dengan tujuan agar pihak lain membeli efek. Window dressing adalah upaya melakukan manipulasi untuk dapat mendapatkan laporan yang baik dalam kaitannya dengan performance sebuah perusahaan yang go-public. ${ }^{6}$ Window dressing merupakan salah satu jenis kejahatan yang membahayakan karena pembeli, yang biasanya hanya mendasarkan pemantauannya pada prospektus, akan salah dalam menentukan sikap untuk membeli atau tidak membeli sahan atas suatu perusahaan yang telah ditawarkan.

Berbagai bentuk pelanggaran dalam pasar modal konvensional di Indonesia juga masih terlihat sangat menonjol. Dalam laporan yang diberikan oleh Bapepam, selama tahun 2002, ada 8 (delapan) perusahaan efek dan 2 (dua) wakil perusahaan efek dicabut izin usahanya. Sedangkan yang dibekukan usahanya mencapai 29 (dua puluh sembilan) perusahaan efek, 4 (empat) wakil perusahaan efek, dan 4 (empat) akuntan publik. Pihak lain yang terkena sanksi karena pelanggaran adalah 186 (seratus delapan puluh enam) emiten, 31 (tiga puluh satu) perusahaan efek, 2 (dua) Biro Administrasi Efek (BAE), 1 (satu) bank kustodian, 1 (satu) wali amanat, 8 (delapan) wakil perusahaan efek, 1 (satu) akuntan publik, 1 (satu) penilai dan 15 (lima belas) pihak lain termasuk direksi dan komisaris emiten yang dikenai sanksi administratif berupa denda. Ditambah 36 (tiga puluh enam) pelaku bursa mendapat sanksi administratif berupa peringatan tertulis. ${ }^{7} \mathrm{Hal}$ ini menunjukkan bahwa dengan segala filosofi yang melatarbelakanginya, pasar modal konvensional tidak sepi dari berbagai pelanggaran yang berupa penipuan, praktek kecurangan dan sejenisnya.

Potensi kejahatan yang muncul pada aktivitas pasar modal tersebut sangat bervariasi, sehingga tidaklah mustahil apabila di berbagai negara yang telah lama mengoperasikan perusahaan bursa efek, terdapat berbagai macam bentuk kejahatan yang sangat membahayakan bagi sekuritas dan kelangsungan pasar modal. Di Amerika Serikat misalnya, ada berbagai kasus kecurangan lain yang lazim terdapat pada sebuah pasar modal, ada Kasus Ahern v.s. Gaussoin tahun 1985, atau kasus Escott v.s.

\footnotetext{
${ }^{5}$ Munir Fuady, op.cit., hlm. 154-156.

"Anang Arief Susanto, "Selamat Datang Pasar Modal Syariah" Kedaulatan Rakyat, 21 Juli 2003.

${ }^{7}$ Editorial BMT Link, "Idealitas dan Realitas PasarModal Islami" http://www.bmtlink.web.id/Berita260303.htm.
} 
BarChris Construction tahun 1968. Penyebab dari berbagai kasus kejahatan yang terjadi adalah tidak atau kurang terbukanya perusahaan sewaktu melakukan penawaran, dan perbedaan penafsiran apakah suatu emisi yang dilakukan perusahaan merupakan emisi ataukah bukan. ${ }^{8}$

Berbagai kejahatan yang muncul dalam pasar modal di luar negeri tersebut mengindikasikan bahwa memang pasar modal, dengan segala kemudahan dan kecanggihannya, telah tampil sebagai sebuah bentuk pasar yang tidak dapat dihindarkan dari berbagai celah-celah kelemahan untuk diterobos dengan berbagai pelanggaran. Karenanya, layak, sistem pasar ini mendapatkan pengaturan yang sangat komprehensif.

Hal ini berarti, jika dalam pasar modal konvensional saja pelanggaran semacam itu mudah terjadi, maka dalam pasar modal syariah, yang aspek persinggungannya dengan bidang lain lebih kompleks dan peluang manipulasinya lebih luas, haruslah dilakukan pengaturan yang lebih sempuma.

\section{Pasar Modal Syariah: Sebuah Alternatif}

Pada prinsipnya, dalam dunia ekonomi dan perdagangan, Islam memberikan prinsip ibahah (kebolehan). Semua bentuk perdagangan, selama yang tidak jelas-jelas dilarang oleh syariah, maka dapat dilaksanakan. Karena itulah, Islam mengakomodasi berbagai bentuk kemajuan dunia perdagangan dengan melakukan perubahan orientasi nilai-nilai yang berkaitan dengan aturan syariah.

Dalam masalah pasar modal syariah, tidak ada perselisihan di kalangan ahli hukum Islam tentang kebolehannya. Semenjak munculnya pasar modal di Indonesia, pembahasan tentang pasar modal dari sudut pandang Islam sudah diintroduksi. Dengan berprinsip antara lain pada al-mashlahah, maka pasar modal ini tidak lagi menghadapi permasalahan hukum dalam Islam.

Dengan dibukanya pasar modal syariah, maka keterlibatan unsur ribawi dan substansi haram yang menjadi ganjalan dalam semua praktek bisnis Islam akan terkurangi secara signifikan. Setidaknya, ada beberapa hal yang dapat dicatat sebagai alasan urgensi keberadaan pasar modal syariah. Sehingga, keberadaan pasar modal syariah bukan hanya penting, namun sangat diperlukan guna terciptanya lembaga keuangan Islam yang lebih luas, karena keberadaan dan operasionalisasi perbankan Islam akan kurang kondusif tanpa adanya dukungan dari berbagai lembaga keuangan lainnya. Lebih lanjut, urgensi pasar modal syariah akan diuraikan berikut ini.

\section{Sebagai pelengkap dari lembaga keuangan Islam yang ada}

Perbankan Islam telah menjamur, disertai juga dengản adanya asuransi dan berbagai bisnis 'Islami'. Hal itu mendorong perkembangan sektor produksi dan industri berbasis pada etika yang sejalań dengan

${ }^{8}$ Asril Sitompul, Pasar Modal, Penawaran Umum dan Permasalahannya (Bandung: Citra Aditya Bakti, 1996), hlm. 139 dan 143. 
prinsip syariah Islam. Jika hubungan antara industri dan produksi tersebut dengan bank dianggap telah 'selesai' dengan tersedianya bank syariah, maka 'Islamisasi' sebuah usaha dari sebuah entitas bisnis, baik yang berkaitan dengan penghimpunan dana lewat go-public maupun proses produksi (terkait juga dengan pembinaan mentalitas pekerja dan hak-hak mereka), serta penjualan produk dapat dianggap hampir mencapai kesempurnaan. Hal yang tidak boleh dilupakan adalah bahwa Undang-Undang Nomor 38 Tahun 1999 tentang Pengelolaan Zakat, telah memberikan peluang bagi sebuah perusahaan untuk dapat membayarkan zakatnya dengan cara dikurangkan dari nilai pajak yang harus disetorkan ke negara, meski dari segi jumlahnya masih sangat kurang signifikan. Artinya, berbagai tahapan dalam sebuah bisnis sudah sedemikian rupa terbingkai dalam 'flow chart aktifitas yang Islami.

Karena itulah, kehadiran pasar modal akan berperan sebagai penyempurna dari alur aktivitas ekonomi yang Islami. Apalagi, setelah diresmikannya BAMUI (Badan Arbitrase Muamalah Insonesia) sebagai lembaga resmi arbitrase bagi berbagai bentuk persengketaan yang terjadi dalam kaitannya dengan lembaga ekonomi berbasis syariah.

\section{Memberi peluang investasi bagi orang Islam}

Uang yang mandek dalam sebuah simpanan akan buruk akibatnya bagi perkembangan ekonomi. Islam, pada hakekatnya melarang adanya penyimpanan uang mandek semacam ini. Hal ini bukan sesuatu yang baru bagi umat Islam. Para ahli hukum Islam pada masa pertengahan (harap dibedakan dengan masa pertengahan dalam peradaban Barat yang dikenal dengan middle ages), sudah menyadari hal semacam ini. Ibnu Hanifah misalnya, dianggap mendahului Tolstoi, ekononom Soviet, beratus-ratus tahun dalam hal ide tentang simpanan masyarakat. Di antara warisan hukum yang dirintis oleh Imam Abu Hanifah adalah bahwa uang yang disimpan mandek (uninvested saved money) tidak melebihi dari rencana kebutuhan (expenditure). Sehingga, beliau hanya 'menahan' uang tidak lebih dari 4000 dirham sesuai yang dibutuhkannya. ${ }^{9}$

Hal tersebut nyata-nyata merupakan anjuran untuk memanfaatkan uang dalam usaha yang produktif. Keberadaan pasar modal syariah, jika demikian, akan menjadi tempat untuk investasi, untuk secara riil ikut menempatkan uangnya dalam alokasi produksi. Hal itu merupakan kunci dari penggerakan sektor ekonomi. Bukan saja bermanfaat bagi pemodal yang bersangkutan untuk mengembangkan kapital, namun juga berfungsi bagi orang lain yang mengambil manfaat dari proses produksi.

Dalam konteks ke-Indonesiaan, keberadaan pasar modal syariah ini jelas merupakan sarana yang sangat proporsional

- Abu Hanifah merupakan pionir madzhab ahl al-ra'y (rasionalis) dalam hukum Islam. Pendapatnya yang semacam ini, sebenarnya sangat wajar muncul karena dia sebagai ahli hukum yang hidup di masyarakat yang multikultur dan kosmopolit. Karena itulah dia disebut 'mengantisipasi pendapat Tolstoy 11 abad lebih awal. Lihat, Charles C. Adams, "Abu Hanifa, "Champion of Liberalism and Tolerance in Islam" dalam lan, Edge, Islamic Law and Legal Theory (New York: New York University Press, 1996), hlm. 382. 
bagi umat Islam. Selama ini umat Islam belum akrab dengan dunia pasar modal. Bukan saja karena memang mereka tidak cukup akrab dengan lembaga keuangan modern semacam itu, namun juga disebabkan adanya apriori terhadap keberadaan lembaga keuangan modern. Dalam pandangan awam, setiap lembaga keuangan hampir digeneralisasi sebagai bank, dan image umat Islam awam tentang bank adalah rente, dan rente itu adalah riba. Karenanya, umat Islam tidak terasa akrab dan tidak berusaha mengenali lebih dekat terhadap lembaga keuangan Islam. Survai yang dilakukan di berbagai propinsi di Indonesia tentang preferensi bank syariah, mayoritas menjawab tidak mengenal produk bank syariah. Mayoritas responden $(84,40 \%)$ menyatakan hal tersebut. ${ }^{10}$

Atas dasar itu semua, maka adanya pasar modal syariah ini merupakan suatu momentum untuk menyadarkan umat akan urgensi dan ke-halal-an usaha lewat jalur investasi. Sehingga, pasar modal syariah, bukan hanya sebagai sarana mediasi untuk mempertemukan investor muslim dan produsen muslim meskipun bursa efek syariah ini sangat terbuka bagi siapapun, termasuk non muslim- juga sebagai sarana untuk mengontrol dan membudayakan perilaku ekonomi Islam. Para investor muslim juga akan ikut mengontrol syariah compliance bagi perusahaan go public tersebut. Di sinilah kemudian akan tercipta secara otomatis mekanisme check and balance oleh pasar, di mana akan terjadi keadaan saling mengontrol antara pihak-pihak yang terlibat dalam pasar modal syariah ini.

\section{Sebagai alternatif sistem ekonomi}

Sebagai layaknya perbankan syariah yang telah terbukti peranannya sebagai pemain baru dalam lembaga keuangan, baik dalam tataran nasional maupun internasional, maka keberadaan pasar modal syariah ini, dari sisi lain, akan menjadi sebuah alternatif bagi pasar modal konvensional. Dalam kaitannya dengan pembicaraan tentang sistem alternatif, maka jika bank syariah telah terbukti resistan terhadap goncangan krisis, maka pasar modal pun diharapkan akan menjadi media investasi yang resistan dan fair.

Untuk mewujudkan sebuah pasair modal yang semacam di atas, tentu sangat penting untuk dilihat, bagaimana perangkat aturan yang seharusnya dibuat dan diterapkan bagi pasar modal syariah ini. Di antara yang sangat penting adalah bagaimana keistimewaan pasar modal jenis ini bagi antisipasi berbagai kejahatan pasar modai sebagai yang sering terjadi dalam pasar modal konvensional. Berbagai kejahatan yang sangat besar dan masif pengaruhnya bagi distabilitas ekonomi, sebagaimana tersebut dalam pembahasan di depan, sangat mungkin terjadi di lantai bursa. Jika hal itu dianggap sebagai ekspresi dari

${ }^{10}$ Survai tentang preferensi bank syariah ini diadakan di berbagai proponsi di Indonesia, di antara kesimpulan penting yang didapat adalah "Penelitian Potensi, Preferensi dan Perilaku Masyarakat terhadap Bank Syariah di Wilayah Jawa Tengah dan Daerah Istimewa Yogyakarta", kerjasama Bank Indonesia dan Pusat Penelitian Kajian Pembangunan, Lembaga Penelitian UNDIP, 2000, hlm 13. dalam http://www.bi.go.id/ bank indonesia2/utama/publikasi/upload/BPS-ES-Jateng-indonesia.pdf. 14 Mei 2004 jam 09.20. 
motif ekonomi yang menyiasati atau melanggar aturan hukum, maka, dalam pasar modal syariah ini, diharapkan, bingkai moralitas keagamaan akan menjadi spirit bagi terciptanya pasar modal yang lebih sportif dan fair. Di sinilah beban berat dari DSN (Dewan Syariah Nasional) terlekat.

\section{Memberikan stimulasi perilaku bisnis secara Islami}

Lembaga keuangan Islam adalah bagian yang sistemik dari sistem ekonomi syariah. Dia merupakan mata rantai yang menyambungkan dari berbagai aktivitas ekonomi syariah. Perilaku bisnis yang sejalan dengan prinsip-prinsip Islam tidak akan dapat tumbuh dengan baik jika tidak ada situasi kondusif yang melingkupinya. Adanya keharusan untuk menaati berbagai prinsip syariah, baik dalam berbagai kontrak yang terjadi ataupun dalam operasionalisasi proses produksi dari perusahaan yang masuk dalam listing di lantai bursa, niscaya akan terbentuk sistem bisnis yang lebih baik. Sehingga, kontrol akan tetap dilakukan, sehingga sangat mungkin akañ menciptakan iklim yang lebih baik bāği teraplikasikannya berbagai prinsip-prinsip bisnis yang sejalan dengan syariah Islam.

\section{Menuju Syariah Compliance}

Suatu hal sangat penting untuk diklarifikasikan sebelum membahas lebih lanjut tentang Syariah compliance adalah, apakah sebenarnya yang menjadikan sebuah pasar modal itu dapat disebut dengan pasar modal syariah? Parameter bagaimanakah yang dapat digunakan untuk menentukan kesyariah-an sebuah pasar modal? Aturan main yang seperti apakah yang seharusnya ada dan terlekat secara built-in dalam pasar modal syariah tersebut agar pasar modal jenis ini tidak mengalami 'konvensionalisasi' dalam realisasi praktisnya?

Sebagai upaya untuk memperjelas hal tersebut, haruslah dimulai dari yang paling mendasar. Dalam dataran konsepsional, pasar modal dapat dikatakan Islami atau syar'i adalah apabila praktek operasional dalam berbagai transaksi dan prosedurnya bersesuaian dengan prinsip-prinsip syariah, dilakukan sesuai aturan-aturan dalam Islam. Di antara prinsip-prinsip syariah dalam muamalah adalah; halal dan baik (halalan thayyiban), tidak menggunakan cara yang bathil, tidak melampaui batas, tidak mengakibatkan kezaliman, termasuk terhindarkan dari riba dan maysir (spekulasi) dan tidak gharar (manipulatif). "Sehingga, sebenarnya dasar konsepnya cukup sederhana. Hanya saja, bahwa pengertian yang masih besifat 'nilai' tersebut tidak mudah untuk diderivasikan ketika harus berhadapan dengan realitas yang sangat praktis dan kompleks. Terlebih dalam dunia ekonomi, yang di situ orang cenderung untuk "mengeluarkan modal yang sekecil-kecilnya untuk mendapatkan keuntungan yang sebesar-besarnya". Untuk itulah, permasalahannya di seputar syariah compliance terhadap pasar modal syariah ini menjadi sangat penting.

Sebenamya, dalam perjalanannya, pasar modal di indonesia telah memiliki rambu-

$"$ BMT Link, loc.cit. 
rambu pengaturan yang cukup jelas. Keberadaan Undang-Undang Nomor 8 Tahun 1995 tentang Pasar Modal (UUPM) sudah cukup memberikan gambaran pengaturan yang relatif gamblang, meskipun pembaharuan undang-undang tersebut sudah diperlukan dikarenakan sosio dan politicoekonomi yang ada juga berkembang. Akan tetapi, pengaturan yang ada tidak menyentuh wilayah esoteris. ${ }^{12}$ Namun haruslah disadari bahwa aspek isoteris bukanlah wilayah juridiksi hukum dan perundang-undangan, sehingga, jika hal itu tidak disebut adalah sesuatu yang wajar. Basis dari pasar modal syariah adalah sebuah norma dan nilai-nilai, sehingga kesesuaian dengan syariah dalam dataran praktek operasionalnya menjadi sangat perlu untuk diperhatikan.

Problem utama dalam hal ini adalah bagaimana nilai-nilai etika dan prinsip-prinsip ekonomi syariah dapat diderivasikan dalam pasal-pasal aturan hukum, sehingga, spirit syariah yang mendasarinya dapat tetap diikuti. Dengan perkataan lain, ada permasalahan tentang metode kanunisasi (legislasi), bagaimana upaya kanunisasi akan dilakukan agar dapat merepresentasikan seluruh sistem nilai Islami dalam al-buyu' atau al-tijarah. Tentu, tidak pada tempatnya dalam tulisan yang sangat terbatas ini untuk membicarakan secara detail bagaimana metode kanunisasi yang akan digunakan dalam konteks ini.

Masalah ketaatan kepada prinsip syariah menjadi pertimbangan yang sangat penting dalam operasionalisasi pasar modal syariah ini. Hampir dapat dikatakan bahwa untuk terjaganya pasar modal syariah agar tidak kehilangan predikat kata terakhir tersebut, adanya bergantung dengan bagaimana bentuk pengawasan syariah dilakukan dan seberapa jauh efektifitasnya. Beberapa langkah yang dapat dilakukan untuk mengupayakan pengawasan syariah compliance pada pasar modal syariah akan dipaparkan berikut ini.

\section{Pembakuan bentuk perjanjian yang sesuai dengan syariah}

Aspek yang dapat dianggap paling sentral peranannya dalam pasar modal syariah ini, sebagaimana juga dalam setiap aktivitas transaksional, adalah perjanjian. Sehingga, pembakuan berbagai bentuk perjanjian yang memang berlandaskan pada prinsip-prinsip syariah harus dilakukan. Unsur-unsur perjanjian yang boleh, termasuk objek yang jelas, tidak eksploitatif dan spekulatif. Berbagai kerugian yang terjadi dalam aktivitas ekonomi dan bisnis banyak yang bersumber dari ketidakjelasan dalam perjanjian yang dilakukan. Adanya standardisasi yang jelas, yang dilengkapi dengan parameter yang terukur, akan mudah ditentukan apakah prinsip-prinsip dasar perjanjian Islam terpenuhi.

Sebuah kontrak yang shahih (valid), menurut Islam, haruslah memenuhi beberapa syarat sebagai berikut:

1) Baik dalam landasan motivasinya. Sebuah motivasi yang tidak baik, yang akan dapat diketahui dari berbagai kesengajaan yang terjadi dalam kesalahan yang diperbuat,

${ }_{12}$ Yang penulis maksud dengan aspek isoteris, misalnya bagaimana motivasi yang harus dibangun dalam pasar modal syariah, spirit pasar yang menjiwainya, dan sebagainya. 
menjadikan cideranya sebuah kontrak. Jadi, meskipun motivasi ini adalah masalah niat seseorang, namun dapat dimungkinkan, beberapa perbuatan yang terjadi merupakan refleksi dari motivasi. Di sinilah sebenamya, Islam menekankan dengan sangat kuat, apa yang dalam hukum barat dikenal dengan asas itikad baik. ${ }^{13}$ Bahkan dalam hal ini, Islam sangat tegas menyatakan bahwa "seluruh perbuatan dapat ditentukan posisi hukumnya atas dasar niat yang melatarbelakanginya". ${ }^{14}$ Sehingga, salah satu yang harus tercermin dalam kontrak yang dilakukan adalah bagaimana klausul yang ada mengakomodasi akan niat yang baik.

2) Tidak mengandung hal-hal yang memberikan akses bagi sesuatu yang dilarang dalam syariah. Kontrak yang melibatkan substansi atau objek yang haram jelas tidak dapat dikatakan sah. Demikian juga dengan kontrak yang mengandung unsur kerugian bagi salah satu pihak.

3) Tidak terkait dengan gambling (maisir), ialah suatu perbuatan yang bersifat mengambil keuntungan dengan tanpa melakukan upaya-upaya yang wajar. Kontrak yang berkaitan dengan lotere, monopoli, melakukan penimbunan (akumulasi) barang untuk dijual dengan harga yang sangat tinggi, adalah beberapa contoh bentuk maisir. Hal-hal yang berupa spekulasi tinggi, juga dapat dimaksudkan dengan klasifikasi ini. ${ }^{15}$

4) Menghindari pemaksaan (restraint). Restraint adalah sebuah pembatasan tertentu yang mengakibatkan seseorang tidak memiliki alternatif lain dalam melaksanakan sesuatu. Misalnya, memaksa pekerja untuk melakukan pekerjaan di luar kewajaran, menarik pajak yang sangat tinggi dengan tidak diimbangi pelayanan yang layak, memberikan klausul yang rasialis bagi pekerjaan tertentu, yang kesemuanya itu diterima oleh salah satu pihak atas dasar keterpaksaan karena tidak ada altematif lain yang dapat dilakukan. Hal ini dapat diambil makna sebagai menghindari pemanfaatan posisi pihak yang lemah untuk mengambil keuntungan di luar

${ }^{13}$ Asas iktikad baik (good faith) merupakan hal yang mendasar dalam kontrak. Bahkan dalam berbagai sistem hukum sekalipun, hukum kontrak ditafsirkan dengan menyandarkan pada iktikad baik tersebut. Lihat Ridwan Khairandy, Iktikad Baik dalam Kebebasan Berkontrak (Jakarta: Pascasarjana Fakuitas Hukum Universitas Indonesia, 2003), hlm. 217. him. 91.

${ }^{14}$ Abdul Karim Zaidan, Al-Madkhal li Dirasah al-Syari'ah al-Islamiyah (Bagdag: Mathba'ah al-'Ani, 1969),

${ }^{15}$ Spekulasi sangat terkait dengan perkembangan fasilitas dalam kehidupan manusia. Artinya, sesuatu yang dianggap spekulatif di masa lalu sangat mungkin berubah menjadi sesuatu yang pasti pada hari ini. Misalnya, jual belibuah-buahan yang sangat tergantung pada cuaca adalah sesuatu yang spekulatif pada masa lalu. Namun dengan ditemukannya teknologi prakiraan cuaca, sebagaimana juga dengan penghitungan gerhana, akan menjadi sesuatu yang tidak spekulatif. Dalam kasus bursa berjangka komoditi (future trading) misainya, akan sangat nampak bahwa kebolehannya secara syari dikarenakan adanya perkembangan teknologi dalam bidang pertanian. 
kewajaran.

5) Mengihindari taghrir dan tadlis, ialah semua tindakan yang mengandung unsur tipu daya yang terjadi atas kesengajaan. Semua bentuk perjanjian yang menyembunyikan suatu kelemahan akan menjadikan cacatnya sebuah perjanjian. Jika di atas ada bentuk kejahatan yang bernama window dressing, maka hal itu merupakan bagian dari bentuk tipu muslihat dalam tema bahasan ini. ${ }^{16}$

\section{Transparansi akuntansi syariah (prospektus syariah)}

Dalam aktivitas muamalah, transparansi merupakan suatu keharusan. Dalam aktivitas perdagangan, kejelasan dan kelengkapan informasi atas sebuah objek yang diperjanjikan merupakan prasyarat mutlak. Bahkan dalam prinsip syariah, setelah informasi yang jelas pun masih diberikan ketentuan adanya masa khiyar. Khiyar ialah tenggang waktu yang secara konvensional disepakati sebagai suatu kesempatan untuk berpikir dan mempertimbangkan, dan tidak menutup kemungkinan untuk mencari informasi lebih detail dari berbagai sumber tentang objek maupun pihak yang akan terlibat.

Sebaliknya, Islam melarang keras berbagai bentuk perdagangan yang tidak menyediakan informasi yang lengkap akan objek yang diperdagangkan. Misalnya, dilarang di dalamnya bai' al-mulamasah, ialah perdagangan yang hanya membolehkan pembeli untuk sekedar menyentuh objek tanpa memeriksa dengan detail. ${ }^{17}$ Sama halnya dengan menjual buah yang masih belum siap panen dan ikan yang masih dalam kolam. Rasul juga melarang para pedagang kota untuk mencegat dan membeli barang dari orang-orang dari desa yang pergi ke kota untuk menjual barang, padahal orang-orang desa tersebut belum mengetahui perkembangan harga terbaru. Membeli sesuatu yang belum jelas, misalnya buah yang belum siap dipanen atau ikan yang berada dalam kolam, adalah contoh lain yang relevan dengan larangan tersebut. ${ }^{18}$

Atas dasar itu, transparansi akuntansi syariah merupakan syarat mutlak bagi jual beli yang adil dalam pasar modal. Dalam wacana modern, kelengkapan informasi itu merupakan jaminan pemenuhan akan hak konsumen. Yang paling penting adalah prospektus bagi perusahaan yang listing di lantai bursa haruslah memberikan informasi yang sejelas-jelasnya tentang berbagai aspek dari perusahaan. Bukan saja sebagaimana yang ada pada perusahaan-yang. listing di pasar modal konvensional, namun lebih jauh lagi harus mencantumkan informasi yang dapat ditentukan akan ke-halal-an modal dan bidang usaha. Bahkan, akan lebih baik jika

${ }^{16}$ Liaquat Ali Khan Niazi, Islamic Law of Contract (Lahore: Research Cell, Dyal Sing Trust Library, 1990), hl.m. 78-79 dan 115 - 123.

${ }^{17} \mathrm{Jbid} ., \mathrm{hlm} .89$.

${ }^{18}$ Agus Triyanta, "Resistensi Sistem Bisnis Islami dan Sistem Bisnis Sekuler terhadap Deviasi Pasar", Jumal Magister Hukum, Vol. 2 No. 4, hlm. 97- 110. 
bukan hanya kejelasan laporan permodalannya, namun juga record tentang berbagai penggunaan dana yang bersifat sosial (charity), termasuk zakat, yang telah diperbuat oleh perusahaan.

Harus kembali kepada tujuan awal: untuk berinvestasi, bukan spekulasi

Antara investasi dan spekulasi memang ada kemiripan. Keduanya sama-sama melakukan aktivitas membeli saham, yang dari kegiatan tersebut akan diperoleh keuntungan. Namun, keduanya memiliki spirit yang sangat berbeda. Spekulan memiliki tujuan untuk membeli saham dan menjualnya kembali, yang dari itu akan diambil keuntungan, sedangkan investor, membeli saham dengan tujuan -untuk berpartisipasi dalam sebuah aktivitas bisnis, dan akan mendapatkan untung dari hal tersebut. ${ }^{19}$ Dalam pandangan Islam, orang yang membeli saham seharusnya bertujuan untuk membangun mutual relation, saling menguntungkan dengan kerja yang nyata.

Dalam kaitannya dengan investasi dan spekulasi ini, Islam sebenarnya telah membangun prinsip-prinsip muamalah sejak dari landasan yang paling mendasar. Sebagaimana terjadi dalam hirarki hukum dan perundang-undangan, muamalah Islam pun, termasuk pasar modal, merupakan derivasi dari sebuah landasan idill yang sangat tinggi. Hal itu menjadi 'alam ide' bagi sebuah sistem perdagangan syariah, yang di bawah itu ada ground norms, dan seterusnya hingga dalam realisasinya yang paling praktikal ialah prinsip perjanjian dan pasar dalam Istam. Melihat dan mengimplementasikan sistem perdagangan syariah dengan tanpa melihat latar belakang nilai yang mendasarinya, hanya akan meletakkan Islam sebagai sebuah fenomena sosial dan salah satu sistem pasar yang dipersepsi secara legal formal. Di sinilah sebenarnya spirit yang harus tertanam bagi orang yang ingin memasuki dan terlibat dalam dunia pasar modal syariah.

Dalam hal ini, yang layak menjadi perhatian dari DSN adalah diformulasikannya semua bentuk spekulasi yang dalam tingkat tertentu akan berakibat madharat bagi keberlangsungan pasar modal syariah. Adanya kejelasan tersebut, menjadikan Syariah compliance sangat jelas parameternya.

Detail permasalahan kesesuaian dengan prinsip-prinsip syariah yang harus diimplementasikan dalam pasar modal syariah, bukan berarti bahwa sudah cukup hanya dengan itu. Tantangan lain yang mengharuskan jawaban yang sungguhsungguh adalah masalah performance, atau tampilan pelayanan. Mengapa hal itu penting? Jelas, bahwa kelak selanjutnya, pasar modal syariah ini akan berkompetisi dengan pasar modal konvensional, sebagaimana yang terjadi dengan perbankan syariah saat ini. Dalam kompetisi yang sangat ketat dan dengan segmen pasar yang semakin kritis dan cerdas, agaknya menyandarkan daya tarik dari faktor emosionalitas yang berupa sentimen keagamaan saja belum cukup. Dalam target jangka panjangnya, sebagaimana yang disebutkan di depan, pasar modal syariah

${ }^{19}$ Irfan Syauqi Beik, loc.cit. 
bukan hanya harus dapat memfasilitasi konsumen muslim, namun lebih dari itu akan menjadi sebuah alternatif dalam 'belantara' pasar dengan berbagai sistem dan nilai yang mendasarinya.

Termasuk dalam kaitannya dengan tantangan ini adalah tentang efisiensi yang harus diciptakan seoptimal mungkin. Meskipun harus disadari bahwa ada 'double burden' yang harus ditanggung dalam pasar modal syariah ini, namun efisiensi tetap harus dicapai. Sebagaimana yang telah ditentukan, struktur organisai dalam semua lembaga keuangan bertambah, dan mekanisme juga makin rumit dikarenakan keharusan adanya pengawasan syariah di samping pengawasan prudential sebagaimana yang terjadi dalam lembaga keuangan konvensional. Keharusan berdiri pada dua kaki tersebut tidak dipungkiri akan menambah beban, utamanya anggaran dan sumber daya.

Adanya berbagai prinsip ideal tersebut, menjadikan permasalahan syariah compliance bukanlah masalah yang sederhana. Bahkan, tingkat kompleksitas dalam masalah ini dapat jadi akan melebihi kompleksitas dalam aspek prudential yang didasari dengan perundang-undangan sebagaimana dalam pasar modal konvensional.

Dengan demikian, pemahaman akan permasalahan dan detail tentang pasar modal yang integral, sekaligus memahami secara lengkap aspek syariah, merupakan prasyarat bagi terwujjudnya Syariah compliance yang ideal dalam pasar modal syariah ini. Instrumen pengawasan syariah pun harus lengkap dan jelas, sehingga terminologi pelanggaran syariah-nya akan dengan mudah ditentukan.

\section{Simpulan}

Dalam pasar modal konvensional, spekulasi adalah hal yang sangat mungkin dan sangat sering dilakukan; meski kegiatan ini mendatangkan banyak kerugian bagi berbagai pihak. Bukan hanya itu, pasar modal juga sangat rentan terhadap berbagai manipulasi dan penipuan. Namun, kemunculan pasar modal syariah, ternyata bukan hanya sebagai wadah dan peluang untuk berinvestasi bagi umat' Islam yang berpegang pada ke-haram-an sistem bunga, namun juga berpeluang untuk menjadi alternatif dari sebuah sistem ekonomi yang lain. Beberapa hal harus diperhatikan dalam rangka upaya penegakan syariah compliance; pembakuan kontrak, transparansi akuntansi syariah, dan reorientasi tujuan untuk berinvestasi.

\section{Daftar Pustaka}

Adams, Charles C., "Abu Hanifa Champion of Liberalism and Tolerance in islam" dalam Edge, lan, Islamic Law and Legal Theory, New York: New York University Press, 1996.

Beik, Irfan Syauqi, "Prinsip Pasar Modal Syariah", http://umw. pesantrenvitual.com/ ekonomi/001.shtml 27 April 2004.

Editorial BMT Link, "Idealitas Dan Realitas

Pasar Modal Islami" http:ll umw.bmtlink.web.id/Berita260303.htm

Fuady, Munir, Pasar Modal Modern (Tinjauan Umum), Bandung: Citra Aditya Bakti, 1996. 
Kertonegoro, Sentanue, Pasar Uang Pasar Modal, Jakarta: Yayasan Tenaga Kerja Indonesia, 1999.

Khairandy, Ridwan, Iktikad Baik dalam Kebebasan Berkontrak, Jakarta: Pascasarjana FH UI, 2003.

Niazi, Liaquat Ali Khan, Islamic Law of Contract, Lahore: Research Cell, Dyal Sing Trust Library, 1990.

Sitompul, Asril, Pasar Modal, Penawaran Umum dan Permasalahannya, Bandung: Citra Aditya Bakti, 1996.

Susanto, Anang Arief, "Selamat Datang Pasar Modal Syariah" Kedaulatan Rakyat, 21 Juli 2003.
Triyanta, Agus, "Resistensi Sistem Bisnis Islami dan Sistem Bisnis Sekuler Terhadap Deviasi Pasar", Jurnal Magister Hukum, Vol. 2 No. 4, 2000.

Zaidan, Abdul Karim, Al-Madkhal li Dirasah al-Syariah al-Islamiyah, Bagdag: Mathba'ah al-'Ani, 1969.

Bank Indonesia dan Pusat Penelitian Kajian Pembangunan, Lembaga penelitian UNDIP. 2000. "Penelitian Potensi. Preferensi Dan Perilaku Masyarakat Terhadap Bank Syariah Di Wilayah Jawa Tengah Dan Daerah Istimewa Yogyakarta", http://www.bi.go.id/ bank indonesia2/utama/publikasi/ 